\title{
The shell of the ostracod Halocypris inflata (Dana, 1849) examined by the ion beam etch technique
}

\author{
TERESA M. SMITH \& RAYMOND H. BATE \\ Department of Central Services, British Museum (Natural History), London SW7 5BD \\ \& SSI (UK) Limited, Tannery House, Tannery Lane, Send, Surrey GU23 7EF
}

\begin{abstract}
Bombardment of the shell of the myodocopid ostracod Halocypris inflata (Dana, 1849) with charged ions (ion beam etch technique) has resulted in the elucidation of the chitin structure of the cuticle. We show that this technique has produced results that support earlier transmission electron microscopical studies and we demonstrate the importance of the ion beam etch technique not only to ostracod research but to the study of organic material in general.
\end{abstract}

\section{INTRODUCTION}

The study of the organic framework of the ostracod shell was initiated by Bate \& East (1972 \& 1975) when they studied Recent freshwater podocopids and marine myodocopids. The selection of these two groups of ostracod was influenced solely by their low incidence of calcification. They were thus not only easier to section but revealed their chitin structure more readily.

Throughout the entire arthropod group there can be recognised a consistency of structure that in transmission electronmicrographs (see Bate \& East, 1975, pl. 4) appears as a 'feathered' arrangement of fibres that form parallel rows of horizontal fibres alternating between broader rows where the fibres are curved (Pl. 1, fig. 3). This structure has often been considered to be an artefact produced by obliquely sectioning a spiral arrangement of chitin sheets (Neville, 1970). Subsequently, the beautifully illustrated work of Mutvei (1974) and of Dalingwater (1975a, b) has shown, for crustacean cuticle, that the fibres or sheets of fibres, bend round between more horizontal layers.

As far as the structure of the ostracod shell is concerned the calcified discs seen in several of our illustrations are purely incidental to our study. A brief discussion of this mode of calcification will be made, however, in the context of Sohn \& Kornicker's work (1969) but the essential details of this unusual calcification may be read in Bate \& Sheppard (1982).

The aims of the present paper are twofold firstly, we wish to demonstrate that the 'feathered' microstructure of the ostracod shell illustrated in earlier papers by means of transmission electron micrographs is supported by the macrostructure obtained by ion beam etching of the specimen and subsequent examination using the scanning electron microscope; secondly, we wish to draw attention to the use of ion beam etching as a tool in the study of organic material.

\section{METHODS}

Ion beam etching has long been used by material scientists for thinning sections of metals and nonconductive materials prior to examination in the transmission electron microscope. Stewart (1962) described a method of etching material using ion beams inside the scanning electron microscope. Later, Boyde \& Stewart (1962) used this technique to examine the structure of teeth, Echlin (1971) examined pollen by the same method and more recently Blackmore \& Claugher (1983) have used a similar method but external to the microscope, in their study of pollen.

In the E.M. laboratory of the British Museum (Natural History), ion beam etching is carried out using a purpose built instrument independent of the microscope. Specimens are bombarded with a beam of ions to remove successive layers of tissue or material thus revealing the underlying structures. These are photographed under the S.E.M. and provide a comparison with the results obtained using transmission electron microscopy.

Ion beam etching is carried out in a vacuum of $10^{-3}$ torr; when a DC voltage is applied to the ion gun, electrons oscillate in the electrostatic saddle-field region of the central anode, and describe long paths increasing the probability of ionization of the gas used. Ionization occurs between $3 \mathrm{kV}$ and $10 \mathrm{kV}$, but requires greater gas pressure below $3 \mathrm{kV}$. Argon is bled into the system through a needle valve and directed through the gun, the gas is ionized by the excited electrons at $\mathrm{Ar}^{2+}$, excited neutrals are also produced, and this constitutes the beam. The output, or ion current, is varied by adjusting the flow of argon into the gun which affects the relationship between the ion beam and the accelerating voltage. The beam is projected through a slit $10 \mathrm{~mm}$ long by $1.5 \mathrm{~mm}$ wide and diverges to produce a wedge-shaped configuration. Uneven etching will occur on irregular or 
unpolished specimens due to shadowing but this is minimised by rotating the specimen in the beam.

In this study, ion beam etching was carried out using a Super Microlap MK2, model B306 with a B216 $10 \mathrm{~mm}$ saddle-field ion source manufactured by Ion Tech Ltd. of Teddington. Alcohol-fixed specimens were dehydrated through graded alcohols and critical point dried before mounting on aluminium stubs with araldite. Specimens were initially etched for 15 minutes at a gun angle of $30^{\circ}$, a voltage of $5 \mathrm{kV}$ and a current of $3 \mathrm{~mA}$ giving an ion beam current of $0.6 \mathrm{uA}$. After etching the specimens were splutter coated with gold palladium and examined using a Cambridge S180 S.E.M. This procedure was repeated with the same specimen for a further period of 15 minutes, and three periods of 30 minutes.

\section{DISCUSSION}

Chitin structure. The carapace of Halocypris inflata (Dana, 1849) seen in TS (PI. 1, fig. 3) has a three layered structure: an outer thin epicuticle covers the entire outer shell surface and forms the upraised ornamental ridges (Pl. 2, fig. 1) that produce a finger-print pattern over the surface (Pl. 1, fig. 1). These epicuticular ridges appear to be calcified (see Geoscan elemental electron micrograph for Ca in Bate \& Sheppard, 1982, pl. 3, fig. 1) and are resistant to ion beam etching as are the calcite discs (Pl. 1, fig. 2). As shown in Bate \& Sheppard (1982, pl. 10, fig. 3) the epicuticular ridges are hollow and it is more probable that the calcification of these ridges is contained within this space.

As can be observed from the transmission electronmicrograph, the epicuticle and the ridges produced do not extend down into the shell matrix. This is an important point to make otherwise the parallel lines seen at depth could be misinterpreted; in fact they are produced by the chitin sheets coming together. The epicuticular ridges, although not homologous with the ornamental ridges described by Okada (1982), could reflect the subsurface outline of the epidermal cells but this is conjectural at this stage.

Exocuticle. This is a layer of unstructured (as presently considered) chitin fibres lying just beneath the epicuticle (Pl. 1, fig. 3), it appears as a rather dense layer when revealed by ion etching (Pl. 1, fig. 4 ; Pl. 2, fig. 1). In transmission electronmicrographs the exocuticle has a more open structure than the 'feathered' endocuticle. In fact in some species of Myodocopida calcification of the carapace appears to be largely limited to the exocuticle (see Bate \& Sheppard, 1982, pl. 3, fig. 5; pl. 7, figs. 1,2). In Halocypris inflata, however, this is not so, the calcite discs cutting down through the exo-and endocuticles (Bate \& Sheppard, 1982, pl. 4, fig. 4; pl. 5, fig. 1).

Endocuticle. In transmission electronmicrographs the endocuticle appears as a 'feathered' arrangment of fibres that curve round (dark layers) between rows of more compacted horizontal layers (light layers). Our illustration of this structure does not extend through the complete thickness of the endocuticle and the reader is referred to Bate \& Sheppard (1982, pl. 6, fig. 1) where it may be seen that the alternating light and dark layers come closer together and are tightly compacted immediately overlying the epidermal cells. Although our illustration of this layer (Pl. 2, fig. 6) is photographed wisucly and the material has suffered some collapse due to ion beam etch thinning of the tissue, we nevertheless consider that the structure illustrated gives some idea as to the compaction of the tissue at the inner surface (base) of the shell. Part of this inner layer of the endocuticle has been considered (Bate \& Sheppard, 1982 , p. 29) to represent new shell tissue produced by the epidermal cells prior to the moulting of the 'old' shell.

The main thickness of the endocuticle is taken up by

\section{Explanation of Plate 1}

Fig. 1. Complete carapace of Halocypris inflata ion beam etched for 30 minutes. Note the irregular distribution of the calcite discs and the 'fingerprint' ornamentation of epicuticular ridges. Specimen illustrated upside down. $(\times 50)$.

Fig. 2. Surface detail of carapace ion beam etched for $1 \frac{1}{2}$ hours. The cuticular ridges, here calcified, stand out in relicf together with the discs of $\mathrm{CaCO}_{3}$. Note distinct secretory pore opening. $(\times 1,500)$.

Fig. 3. Transmission electron micrograph of a transverse section through the shell of Halocypris inflata. Epi-epicuticle; Exo-unstructured exocuticle; End-endocuticle showing 'feathered' structure of the chitin. $(\times 18,200)$.

Fig. 4. Shell after etching for 30 minutes; epicuticular ridges and calcite discs stand out in relief from the unstructured exocuticle (Epi of Fig. 3). $(\times 2,400)$.

Fig. 5. Shell after etching for 2 hours revealing 'feathered' structure of endocuticle. $(\times 880)$. 

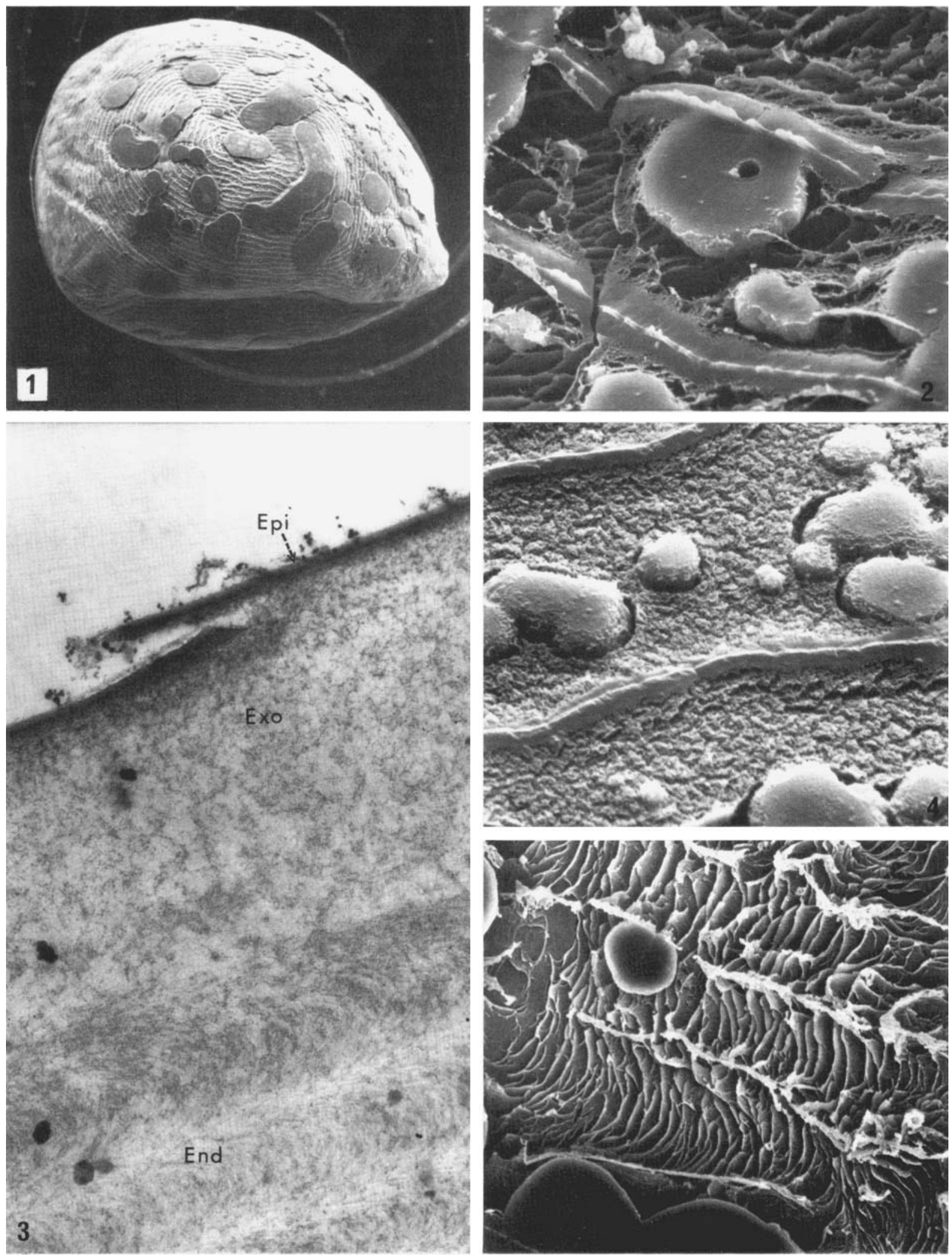
widely spaced layers that in transverse section appear as fibres of chitin. Our scanning electron micrographs of ion beam etched tissue reveal only the chitin macrostructure of sheets of chitin curving between rows of horizontal layers (Pl. 1, fig. 5). The fibres shown in Pl. 1, fig. 3 indicate the microstructure of these chitin sheets (Fig. 1).

These sheets of chitin (themselves probably formed of fibres as seen in Mutvei (1974) but not yet shown in our etched material) are clearly demonstrated in Pl. 1, fig. 5 and Pl. 2, figs. 3, 5. Where the sheets of chitin come together, parallel rows of compressed chitin are produced which, after ion beam etching, appear as upraised ridges (see Pl. 1, fig. 5 and PI. 2, figs. 2-6). These ridges are not synonymous with the epicuticular ridges (as demonstrated in T.E.M.) although ion beam etched sections might lead the reader into thinking that they are. The importance of testing the results of one

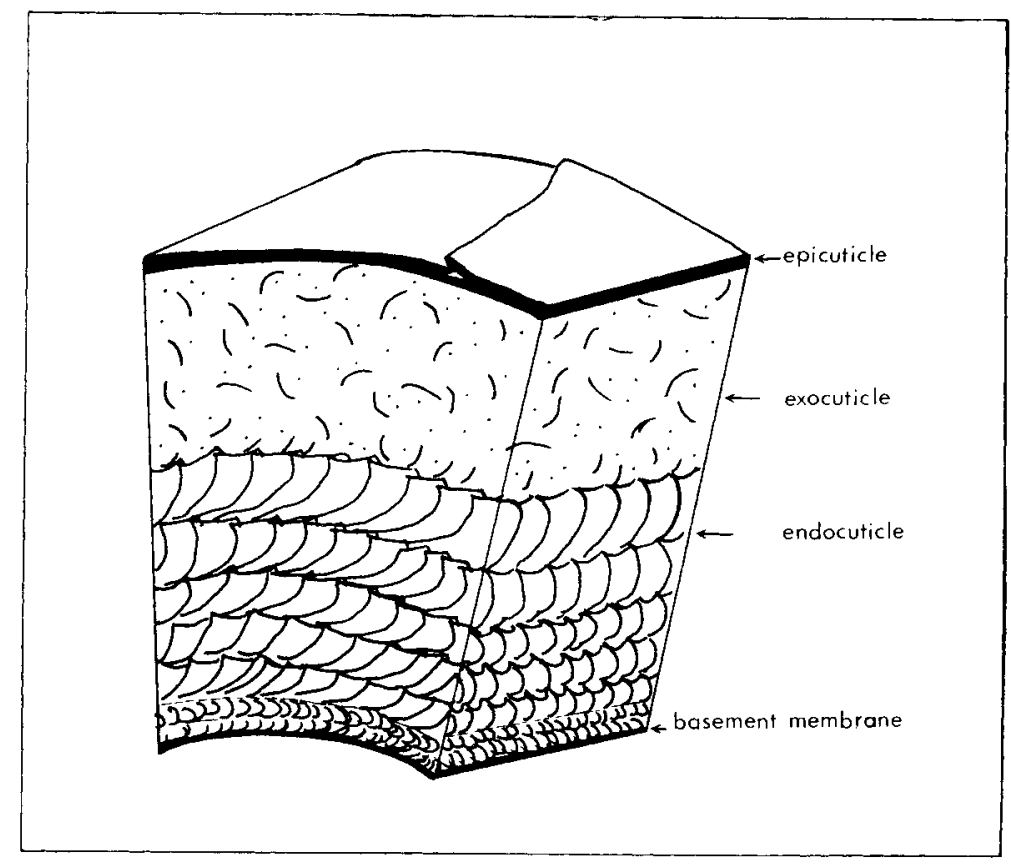

Fig. 1 Diagrammatic section through the shell of Halocypris inflata to demonstrate the lamellar structure and the curved sheets of chitin in the endocuticle as shown by the ion beam etch technique.

\section{Explanation of Plate 2}

Fig. 1. Surface of shell after etching for 30 minutes showing epicuticular ridges, secretory pore aperture and unstructured exocuticle. $(\times 3,800)$.

Fig. 2. Shell after etching for one hour; epicuticular ridges still remain but etching has stripped down to the endocuticle. Resistant calcite discs show little sign of etching. $(\times 610)$.

Fig. 3. Detail of endocuticle after etching for $1 \frac{1}{2}$ hours. The 'feathered' structure of the endocuticle appears as chitin sheets; dense ridges produced where chitin sheets come together. $(\times 4,500)$.

Fig. 4. Detail of endocuticle after etching for $1 \frac{1}{2}$ hours. $(\times 1,400)$.

Fig. 5. 'Feathered' structure of endocuticle after etching for $1 \frac{1}{2}$ hours illustrating curved sheets of chitin. $(\times 1,800)$.

Fig. 6. Endocuticle almost etched away after 2 hours; collapse of structure has occurred, although this could indicate the tighter structure of new cuticle formed prior to moulting. $(\times 680)$. 

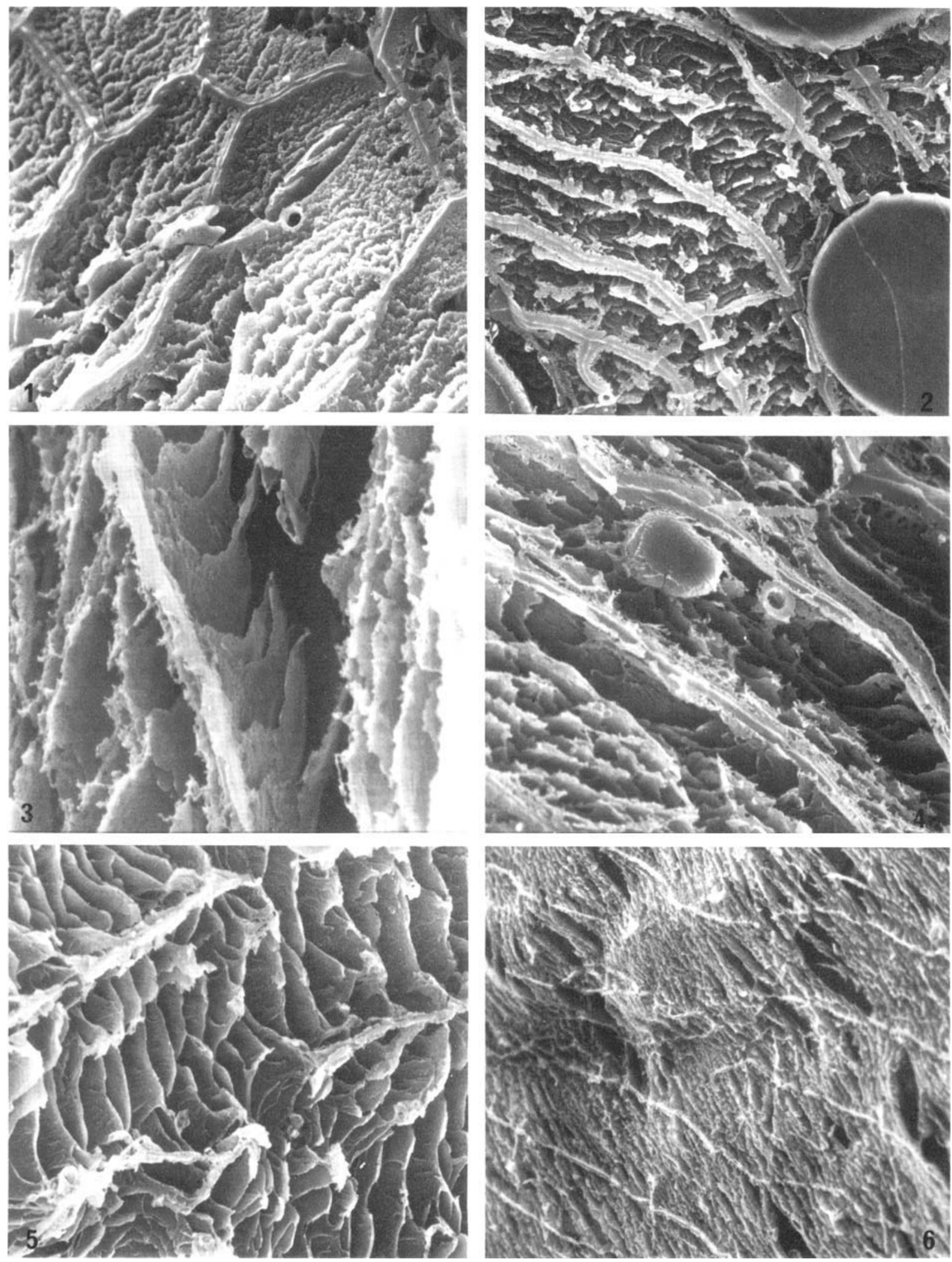
technique by that of another are demonstrated forcibly by this.

Calcification. The calcification observed in Halocypris inflata (and subsequently seen in some myodocopids collected in the Arabian Gulf) contrasts with the uniform layer calcification seen in the myodocopids Conchoecia valdiviae and Codonocera polygonia (see Bate \& Sheppard, 1982) in that it takes the form of discs of calcium carbonate that sometimes coalesce to produce larger patches of calcification (Pl. 1, fig. 1). Sohn \& Kornicker (1969) demonstrated that by taking non-calcified myodocopids (preserved in alcohol) and immersing them in either ordinary tap water, distilled water, sea water or artificial sea water, sphaerulites of calcium carbonate would develop within the shell. The sphaerulites so formed, however, are not comparable with the substantial calcite discs present here in Halocypris inflata. Indeed, the calcification present in this species did not develop in the laboratory as the ostracods have been stored in alcohol since they were trawled from the Atlantic during one of the scientific cruises of HMS Discovery. More rarely, some individuals are completely uncalicified and we have considered that this could be due to the ostracod having been caught and killed just after moulting and before it had time to calcify its new shell.

As with all E.M. techniques, ion beam etching is not without its problems. Results achieved are subject to correct interpretation for the fullest contribution to be made from them. One of the problems involved the evenness with which the specimens were etched. The curvature of the ostracod, its eccentric position on the stub and the non-uniform intensity of the beam produced varying depths within the shell being reached during the same etching period. Some areas were almost entirely etched away (Pl. 2, fig. 6) with collapse of the surface and compression of the structural elements occuring. Some heat is also generated from the etching process and this is dissipated through the specimen. Characteristic distortion of structure is observed after prolonged etching ( 2 hours or more) of various different specimens. It is not known if local heating causes these effects but this could be a contributary factor.

\section{CONCLUSIONS}

The chitin matrix of the shell in Halocypris inflata is demonstrated to consist of an outer exocuticle composed of apparently non-aligned fibres and an inner endocuticle composed of parallel rows of curved sheets of chitin. The more compact layers of the endocuticle are formed by the fusing of these sheets of chitin. The 'feathered' microstructure previously demonstrated only by T.E.M. is thus mirrored by the macrostructure seen in the 'solid' using the ion beam etch technique.

An outer organic layer, the epicuticle, covers the entire outer lamella of the carapace. This epicuticle is upraised to produce a series of parallel ridges that, in transverse section, are hollow. As the epicuticular ridges are calcified, in those specimens examined, it is considered that the calcification is restricted to the space within the ridge. These ridges are not continued at depth within the shell (Bate \& Sheppard, 1982, pl. 10, fig. 3).

The ion beam etch technique is shown to be capable of supporting evidence for structures previously observed in transverse section and to have considerable potential in elucidating the sub-surface structures of organic material to varying depths and in a controllable manner. The technique has proven its potential for ostracod research and its use in other areas of biology is currently being explored. Given further testing and experience as to duration of etching, this technique could prove of use to a wide variety of disciplines.

\section{REFERENCES}

Bate, R.H. \& East, B.A. 1972. The structure of the ostracode carapace Lethaia, Oslo, 5, 177-194.

Bate, R.H. \& East, B.A. 1975. The ultrastructure of the ostracode (Crustacea) integument. Bull. Amer. Paleont., Ithaca 65, 529-547.

Bate, R.H. \& Sheppard, L.M. 1982. The shell structure of Halocypris Inflata (Dana, 1849), 25-50. In Bate, R.H., Robinson, E. \& Sheppard, L.M. (Eds.), Fossil and Recent Ostracods, Ellis Horwood, Chichester for British Micropalaeontological Society.

Blackmore, S. \& Claugher, D. 1983. In press. Ion beam etching in palynology. Grana., Uppsala.

Boyde, A. \& Stewart, A.D.G. 1962. Investigation of the erosion of tooth sections with an argon ion beam. Electron Microscopy V International Congress Philadelphia 1962. Vol. II. Academic Press, New York.

Dalingwater, L.E. 1975a. SEM observations on the cuticle of some decapod crustaceans. Zool. J. Linn. Soc., London, 56, $327-330$.

Dalingwater, L.E. 1975b. The reality of Arthopod cuticular laminae. Cell. Tiss. Res., Berlin, 163, 411-413.

Echlin, P. 1971. The application of SEM to biological research, Phil. Trans. Roy. Soc. Lond. B., 261, 51-59.

Mutvei, H., 1974. SEM studies on Arthropod endoskeletons Part 1: Decapod crustaceans, Homarus gammarus L. and Carcinus maenas (L.) Bull. geol. Inst. Univ. Upsala., 4, 73-80.

Neville, A.C. 1970. Cuticle ultrastructure in relation to the whole insect, 17-37. In Neville, A.C. (Ed), Insect Ultrastructure, Symposia No. 5, Roy. Entom. Soc.

Okada, Y. 1981. Structure and cuticle formation of the reticulated carapace of the ostracode, Bicornucythere bisanensis. Lethaia, Oslo, 15, 85-101

Sohn, I.G. \& Kornicker, L.S. 1969. Significance of calcareous nodules in mydocopid ostracod carapaces, 99-108. In Neale, J.W. (Ed.), The Taxonomy, Morphology \& Ecology of Recent Ostracoda. Oliver \& Boyd, Edinburgh.

Stewart, A.D.G. 1962. Investigation of the topography of ion bombarded surfaces with the scanning electron microscope. Electron Microscopy V international Congress. Philadelphia $1962 \mathrm{Vol}$. 1. Academic Press, New York. 